\section{Translation as Tribute}

Thomas Kabdebo (ed.), A Tribute to Attila József on the 70th Anniversary of His Death (Courtenay Hill: Abbey Press, 2007)

As anyone who has ever applied for a job knows, CVs require an inconvenient balance between the personal and the impersonal. You are supposed to present a full and sincere account of your life and knowledge, but paradoxically you are also expected to suppress the really interesting stuff: your joys and sorrows, your regrets and hidden desires. You can put it into a narrative or just list the facts, but you should not even consider showing your sense of humor or adding a touch of self-irony in the clever arrangement of the material or an unusual turn of phrase. CVs are boring, and we can live with that, and that is one of the reasons why Attila József's "Curriculum Vitae," the first text by the Hungarian poet in the volume entitled $A$ Tribute to Attila József on the 7oth Anniversary of his Death, provides interesting reading. József's narrative CV keeps all the formal conventions of the genre, it provides significant dates, information about qualifications, and ends with the enumeration of the poet's marketable skills, knowledge of languages, familiarity with business cor- respondence, shorthand, etc.: "I am familiar with the technicalities of printing and can express myself clearly and precisely. I consider myself to be honest and I am, I think, intelligent and a hard worker" (17). You don't have to read between the lines, however, to realize at once that József uses these conventional elements to convey information about the things that are not normally included in CVs. Thus, we read about his childhood suffering, the loss of his mother, his conflict with one of his university professors, and the reception of his poems by his friends, and his enemies: "nor did they [his senior colleagues at Mauthner Bank] omit to chaff me about my poems appearing in the press. 'I used to write poetry when I was your age' - they would say. Some time later the bank failed."

Like many Hungarians who had been taught their Attila József at secondary school - much of the school curriculum concerning 2oth century Hungarian poetry is focused on his poetry - I have read József's CV often enough to interpret it in direct relation to the poems as a possible frame of reference for, or an extension of the author's poetic oeuvre. Many readers have been socialized in this way, to commit all the major New Critical fallacies on József's work, and I cannot even say they are totally wrong, since the intensely personal 
voice of the poet invites comparison with the life (i.e. the several different accounts of it at our disposal). Nevertheless, this indulgence in the obvious could prevent us from noticing certain aspects of the texts, and I had to read the lines quoted above in translation to realize the wry humour informing József's account of his work experience at Mauthner Bank. As any good rendering, the English text of "Curriculum Vitae" transforms its source at unexpected points, surprising readers who are familiar with the Hungarian version by making the straight crooked and the plain places rough. It is of course not only the poet's autobiography that provides such surprises: the Tribute volume contains an extensive, chronologically arranged selection of József's poetry in translation which abounds in such instances. Two examples will suffice: the very first poem of the volume, the 1922 "Winter" starts with the line "We should build a bonfire, a superduper one," while in the final stanza of the poet's last piece, the 1937 "Behold I have found my land" we read: "The spring is good and summer, too, / But autumn better and winter best / For him who finds his last hopes through / Family hearths he knew as guest." In both cases the Hungarian original is reshaped significantly; in "Winter," a touch of light irony is highlighted in the solemnity of the original (literally: "We should build some big-big fire") through the use of the colloquial "super-duper," whereas in "Behold I have found my land," the last two lines significantly soften the chillingly hopeless Hungarian lines (literally: "For him who hopes for a hearth and a family only for others") by emphasizing memory as a source of positive hope. Here, and in many of the translations published in the Tribute, it is refreshing to recognize emerging traits that have for the most part remained outside the scope of the mainstreams of the Hungarian critical reception.

But of course A Tribute to Attila József was published for an Englishspeaking audience not necessarily familiar with or interested in the poems' relation to their originals or the traditional ways of interpreting József's oeuvre, so the question comes up: what extra pleasure (besides that of the poems) could these "innocent readers" derive from this collection? After all, as the editor, Thomas Kabdebo points out, the volume represents the fourteenth attempt to turn Attila József's poetry into English - and we might note that a fifteenth book of translation also appeared in the meanwhile (A Transparent Lion, trans. Gábor Gyukics and Michael Castro [Los Angeles: Green Integer, 2006]) - making the poet one of the most widely received 
Hungarian authors in the Englishspeaking world. One possible answer to this question lies in the latter fact: by selecting seventy-three translations by nineteen translators Kabdebo created an anthology of verse which, besides offering an up-to-date, accessible collection of József's major poems also functions as a reservoir of the historical reception by featuring earlier, often out-of-print translations of individual poems. Furthermore, it should be pointed out that the selection is not simply a "best of" collection of Attila József's poetry; alongside the highly serious, and in the Hungarian reception immensely influential "great" poems ("With a Pure Heart," "Ode," "Consciousness," "By the Danube," etc) there are lighter pieces ("I never yet saw a pig," "Keep going!," etc) as well as poems usually included within anthologies of children's literature ("Bear dance," "Lullaby," etc). If anything is missing, it is the juvenilia, especially the poet's very first piece ("Kedves Jocó!" approximating "Dear Jo!"), which, with its wishful and wish-fulfilling fantasies already anticipates József's lifelong obsession with privation and desire as well as the powerfully concrete imagery of his mature work.

Another interesting feature of the volume is that the seventy-three poems (sufficient by all means to stand alone) are provided with a frame: they are preceded by Peter Denman's introduction, and some of the poet's prose ("Curriculum Vitae," "Old Shuffler, the Cobbler" which is a tale known to every Hungarian schoolchild, and a philosophical fragment entitled "Reality and Truth" by the editor), and followed by a handful of tribute-poems by late 2oth century authors, and a selection of critical essays. The tribute-poems are written mostly by Hungarian poets, and testify to the influence József's poetry has been exerting on Hungarian literature for the past decades, while the long free verse lines of John W. Wilkinson in his "Homage to Attila József" provide an important glimpse of the different contexts of the foreign reception.

The scholarly essays deal with three different aspects of József's work: Zsuzsa Beney reinterprets the theme of death in the poet's oeuvre, István Cserne dismantles some of the myths surrounding the poet's life, and Thomas Kabdebo discusses the possible interpretive frameworks available to appreciate the language of the "Ode," József's most famous love poem. The latter study, as well as the volume's preface implicitly posit the "Ode" (and thus József's love poetry in general) as the center of József's work; this strategy (I presume) strikes a balance between the several different interpretive possibilities present 
throughout the poems (philosophical, psychological, socially-oriented and socialist perspectives), it surely helps introduce English-speaking readers to the complex interdependence of the different aspects and themes of József's poetry.

One of the points repeatedly made in several texts of this interpretative framework is that József was a contemporary of the so-called highmodernists (Eliot, Pound, Auden, etc.), but his poetry is very different from theirs. The tribute rendered to the poet may, therefore, be interpreted as salutation, the recognition of a remote poetic style by the inheritors of anglophone modernism (the translators, the poets, and the audience). On another level, however, "tribute" may be interpreted as a debt to be cleared, i.e. as if seventy years after József's death his work still needed introduction and translation into English. Due to the constant need for new translations and new interpretations, it is the nature of such debts to remain ever-standing; nevertheless, the volume edited by Kabdebo goes a long way toward paying a large, if not the final, installment.

Miklós Péti 